\title{
Prediksi Jumlah Pengunjung Perpustakaan Universitas Sam Ratulangi Manado Menggunakan Metode Dekomposisi
}

\author{
${ }^{1}$ Olvi J. Kendek, ${ }^{2}$ Jantje D. Prang, ${ }^{3}$ Marline Paendong \\ ${ }^{1}$ Program Studi Matematika, FMIPA, UNSRAT, olvikendek88@gmail.com \\ ${ }^{2}$ Program Studi Matematika, FMIPA, UNSRAT, jant je dprang@ yahoo.com \\ ${ }^{3}$ Program Studi Matematika, FMIPA, UNSRAT, marline_paendong@yahoo.com
}

\begin{abstract}
Library is a information center that must be managed properly in order to benefit as much as possible. This study aims to determine fluctuations and forecasting the number of visitors at the Sam Ratulangi University (UNSRAT) Library Manado using Decomposition method. The data used are the secondary data of number visitors at UNSRAT library since 2010-2012 were obtained from the UNSRAT library. Research procedure begins by analyzing the components of the decomposition that is trend component $(T)$, seasonal $(S)$, cyclical $(C)$ and a random component (I) and then multiplying the value of these components. Results of forecast showed that the number of visitors in 2013 amounted to 428 visitors on January, 482 visitors on February, 688 visitors on March, 469 visitors on April, 423 visitors on May, 262 visitors on June, 214 visitors on July, 203 visitors on August, 288 visitors on September, 524 visitors on October, 371 visitors on November and 261 visitors on December. It can be seen that the number of visitors increased on February to March and September until October.
\end{abstract}

Keywords : Decomposition Method, Library, Forecasting

\begin{abstract}
Abstrak
Perpustakaan merupakan pusat informasi yang harus dikelola dengan baik agar dapat memberikan manfaat semaksimal mungkin. Penelitian ini bertujuan untuk mengetahui fluktuasi dan meramalkan banyaknya pengunjung di Perpustakaan Universitas Sam Ratulangi (UNSRAT) Manado meng gunakan metode Deko mposisi. Data yang digunakan adalah data sekunder ju mlah pengunjung perpustakaan UNSRAT sejak tahun 2010 - 2012 yang diperoleh dari perpustakaan UNSRAT. Prosedur penelitian dimulai dengan menganalisis komponen-komponen dekomposisi yaitu komponen trend (T), musiman (S), siklis (C) dan komponen acak (I) kemudian mengalikan nilai dari komponen-komponen tersebut. Hasil prediksi menunjukkan bahwa jumlah pengunjung pada tahun 2013 bulan Januari sebesar 428 pengunjung, Februari 482 pengunjung, Maret 688 pengunjung, April 469 pengunjung, Mei 423 pengunjung, Juni 262 pengunjung, Juli 214 pengunjung, Agustus 203 pengunjung, September 288 pengunjung, Oktober 524 pengunjung, November 371 pengunjung dan bulan Desember 261 pengunjung. Dapat dilihat bahwa jumlah pengunjung men ingkat pada bulan Februari sampai Maret dan bulan September hingga Oktober.
\end{abstract}

Kata Kunci : Metode Deko mposisi, Perpustakaan, Prediksi

\section{Pendahuluan}

Perpustakaan yang terbentuk dari istilah librarius yang artinya tentang buku [7], yang mencakup suatu ruangan yang merupakan bagian dari gedung (bangunan) atau gedung tersendiri yang berisi buku-buku koleksi yang diatur dan disusun demikian rupa sehingga mudah untuk dicari dan dipergunakan apabila sewaktu-waktu diperlukan oleh pembaca [6] merupakan pusat informasi dimana bahan-bahan perpustakan dikumpulkan, diolah, disimpan dan dipelihara untuk kemudian disebarluaskan agar dapat dimanfaatkan semaksimal mungkin oleh pengguna perpustakaan. Perpustakaan Universitas Sam Ratulangi (UNSRAT) Manado merupakan salah satu fasilitas utama yang disediakan untuk menunjang sarana pendidikan di Universitas Sam Ratulangi Manado. Kegiatan atau jasa utama perpustakaan adalah peminjaman buku dan materi lainnya sehingga salah satu tolak ukur keberhasilan perpustakaan adalah dengan tingkat pinjaman buku atau banyaknya kunjungan masyarakat (mahasiswa, dosen dan tenaga pendidikan yang ada di lingkungan Universitas Sam Ratulangi) di perpustakaan. Pengelola perpustakaan (pustakawan) perlu mengetahui apakah masyarakat memahami pentingnya peranan perpustakaan dalam hal pendidikan. Untuk itu perlu dibuat suatu "ramalan". Ramalan yaitu memperkirakan sesuatu pada waktu yang akan datang berdasarkan data masa lampau yang dianalisis secara ilmiah, khususnya menggunakan 
metode statistika [5]. Terdapat dua jenis peramalan berdasarkan pendekatan yaitu Peramalan Kualitatif dan Kuantitatif. Pada penelitian ini digunakan model Deret Waktu yang merupakan bagian dalam peramalan kuantitatif. Di sini data masa lampau dikumpulkan, dipelajari dan dianalisis dihubungkan dengan perjalanan waktu yang hasilnya dapat menyampaikan sesuatu yang akan terjadi di masa yang akan datang. Dengan demikian seorang pustakawan yang bertanggung jawab perlu untuk mengetahui hasil peramalan akannaik atau turun banyaknya pengunjung tahun depan. Data dalam deret waktu dapat dikatakan stasioner jika tidak ada perubahan kecenderungan dalam rata-rata dan perubahan variansi. Dengan kata lain, deret waktu yang stasioner adalah re latif tidak terjadi kenaikan atau penurunan nilai secara tajam (fluktuasi data berada pada sekitar nilai rata-rata konstan) [4].

Dalam penelitian ini, metode dekomposisi digunakan untuk meramalkan jumlah pengunjung di Perpustakaan Universitas Sam Ratulangi Manado. Metode dekomposisi (pemecahan) terbagi dalam 4 komponen (pola) perubahan yaitu tren (T), fluktuasi musiman (S), fluktuasi siklis (C), dan perubahan-perubahan yang bersifat acak atau random (I). Keunggulan metode ini dalam peramalan adalah pola atau komponen-komponen tersebut dapat dipecah atau didekomposisi menjadi sub pola yang menunjukkan tiap-tiap komponen deret berkala secara terpisah dan pemisah tersebut seringkali membantu meningkatkan ketepatan dalam peramalan dan membantu atas deret data secara lebih baik.

Dalam penelitian ini kita akan melihat fluktuasi pengunjung pada tahun 2010-2012 di Perpustakaan Universitas Sam Ratulangi Manado serta prediksi banyaknya pengunjung perpustakaan pada tahun 2013 di Perpustakaan Universitas Sam Ratulangi Manado. Hal ini adalah sebagai bahan perencanaan bagi instansi dalam memperbaiki dan mengembangkan fasilitas jika terdapat masih ada yang kurang, serta pelayanan yang memenuhi kenyamanan dan kebutuhan pengunjung perpustakaan sehingga dapat mempertimbangkan hal-hal apa saja yang diperlukan dalam pengambilan keputusan yang tepat untuk meningkatkan kualitas sarana dan prasarana.

\section{Metode Dekomposisi (Me tode De ret Berkala)}

Prinsip dasar dari metode dekomposisi deret berkala adalah mendekomposisi (memecah) data deret berkala menjadi beberapa pola dan mengidentifikasi masing-masing komponen dari deret berkala tersebut secara terpisah. Pemisahan ini dilakukan untuk membantu meningkatkan ketepatan peramalan dan membantu pemahaman atas perilaku deret data secara lebih baik [2]. Metode Dekomposisi atau sering juga disebut metode deret berkala adalah salah satu metode peramalan yang didasarkan pada kenyataan bahwa biasanya apa yang telah terjadi akan berulang atau terjadi kembali dengan pola yang sama, artinya yang dulu selalu naik, pada waktu yang akan datang biasanya akan naik juga, yang biasanya berkurang akan berkurang juga, yang biasanya berfluktuasi akan berfluktuasi juga dan yang biasanya tidak teratur maka akan tidak teratur juga [5].

Perubahan suatu hal tersebut biasanya mempunyai pola yang agak kompleks, misalnya ada unsur kenaikan, berfluktuasi dan tidak teratur. Jika data dengan karakteristik tersebut dimode lkan secara sekaligus maka akan sangat sulit, sehingga biasanya diadakan pemecahan ke dalam empat komponen pola perubahan yaitu: trend (T), fluktuasi musiman (S), fluktuasi siklis (C) dan perubahan-perubahan yang bersifat random (I). Masing-masing pola perubahan akan dicari satu persatu, setelah ditemukan akan digabungkan lagi menjadi nilai, prediksi atau ramalan [5]. Metode dekomposisi digunakan untuk meramalkan data deret berkala yang menunjukkan adanya pola trend dan pengaruh musiman. Metode dekomposisi merupakan suatu metode peramalan yang menggunakan empat komponen utama dalam meramalkan nilai masa depan. Keempat komponen tersebut antara lain trend, musiman, siklis dan error. Metode dekomposisi dilandasi oleh asumsi bahwa data yang ada merupakan gabungan dari beberapa komponen, secara sederhana digambarkan sebagai berikut:

$$
\begin{aligned}
\text { Data } & =\text { Pola }+ \text { error } \\
& =f(\text { trend }, \text { siklis, musiman })+\text { error }
\end{aligned}
$$

Komponen kesalahan (error) diasumsikan sebagai perbedaan dari kombinasi komponen trend, siklis dan musiman dengan data sebenarnya [1]. Asumsi di atas artinya terdapat empat komponen yang mempengaruhi suatu deret waktu, yaitu tiga komponen yang dapat diidentifikasi karena 
memiliki pola tertentu, yaitu: trend, siklis dan musiman. Persamaan matematis umum dari pendekatan dekomposisi adalah:

$$
X_{t}=f\left(T_{t}, S_{t}, C_{t}, I_{t}\right)
$$

dimana $\quad X_{t}=$ nilai deret berkala (data aktual) pada periode $t$

$T_{t}=$ komponen trend (trend) pada periode $t$

$S_{t}=$ komponen musiman (seasonal) pada periode $t$

$C_{t}=$ komponen siklis (cyclic) pada periode $t$

$I_{t}=$ komponen kesalahan tidak beraturan (irregular) pada periode $t$

$t=$ periode $($ time $)$

Dalam metode dekomposisi terdapat model dekomposisi aditif dan multiplikatif. Model dekomposisi aditif dan multiplikatif dapat digunakan untuk meramalkan faktor trend, musiman dan siklis [2], metode dekomposisi rata-rata sederhana berasumsi pada model aditif. Secara matematis dapat ditulis:

$$
X_{t}=T_{t}+S_{t}+C_{t}+I_{t}
$$

Sedangkan metode dekomposisi rasio pada rata-rata bergerak berasumsi pada model multiplikatif yang secara matematis dapat ditulis:

$$
X_{t}=T_{t} \cdot S_{t} \cdot C_{t} \cdot I_{t}
$$

Komponen kesalahan diasumsikan sebagai perbedaan dari kombinasi komponen trend, siklis, musiman dengan data yang sebenarnya. Asumsi tersebut mengandung pengertian bahwa terdapat empat komponen yang mempengaruhi suatu deret waktu, yaitu 3 komponen yang dapat diidentifikasi karena memiliki pola tertentu yaitu trend, siklis dan musiman, sedangkan komponen error tidak dapat diprediksi atau diramalkan karena tidak memiliki pola yang sistematis dan mempunyai gerakan yang tidak beraturan.

Langkah-langkah penggunaan metode Dekomposisi untuk forecasting [3] yaitu :

a. Menyusun data harian/ ming guan/ bulanan/ kuartalan masing-masing tahun.

b. Membuat scatter diagram garis trend linier.

c. Menghitung besarnya nilai trend.

\section{Metode Penelitian}

Pengambilan data jumlah pengunjung perpustakaan dilakukan pada bulan September 2013, dan pengambilan data di Perpustakaan Universitas Sam Ratulangi Manado, Sulawesi Utara. Data yang diambil merupakan data sekunder jumlah pengunjung per bulan selama 3 tahun terakhir yaitu pada tahun 2010-2012.

Langkah-langkah untuk menganalisis data dalam memprediksi jumlah kunjungan di Perpustakaan Universitas Sam Ratulangi Manado dengan menggunakan metode dekomposisi adalah sebagai berikut :

1. Membuat pola time series untuk mengetahui model data.

2. Menyusun rata-rata data jumlah pengunjung tiap bulannya untuk masing-masing tahun.

3. Analisis komponen trend, musiman, siklis dan irregular untuk jumlah pengunjung perpustakaan di Perpustakaan Universitas Sam Ratulangi Manado dengan menggunakan software Minitab 14.

4. Melakukan prediksi untuk data ke depan dari jumlah pengunjung perpustakaan dengan metode dekomposisi model multiplikatif (perkalian).

5. Uji validasi data Januari - Juni 2013.

\section{Hasil dan Pembahasan}

\subsection{Plot Data Pengunjung Perpustakaan Universitas Sam Ratulangi Manado}

Time Series Plot terhadap jumlah pengunjung perpustakaan UNSRAT Manado dari Januari 2010 - Desember 2012 dapat dilihat pada Gambar 1, dimana pola time series berulang pada waktu tertentu. Rata-rata jumlah pengunjung meningkat pada bulan Maret, stabil hingga bulan Mei dan kembali mengalami penurunan pada bulan Juni-Agustus. Peningkatan terjadi lagi pada bulan September - November dan kembali menurun pada bulan Desember. Pola ini menunjukkan fluktuasi pola data time series musiman. 


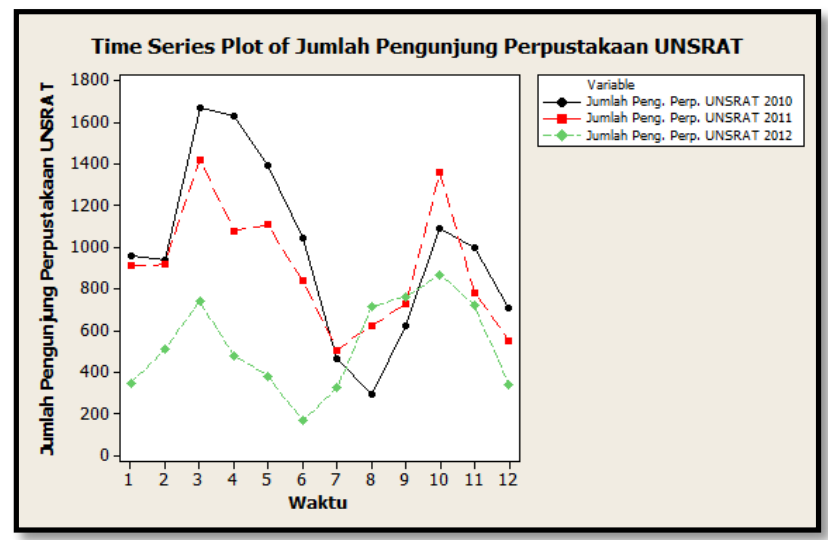

Gambar 1. Plot Data Ju mlah Pengunjung Perpustakaan UNSRAT Tahun 2010-2012

Untuk lebih je lasnya kita akan melihat dalam bentuk grafik Autocorrelation Function (ACF) dan Partial Autocorrelation Function (PACF) berikut ini.

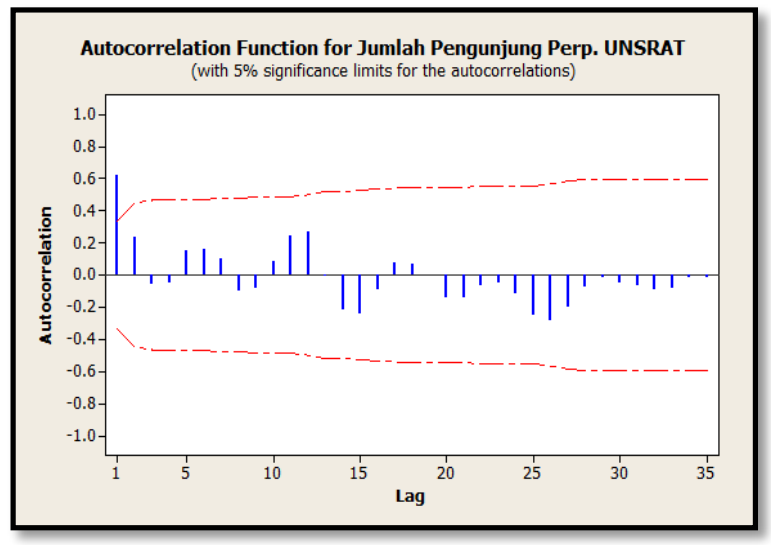

Gambar 2.Grafik Autocorrelation Function (ACF) Jumlah Pengunjung Perpustakaan UNSRAT Tahun 2010-2012

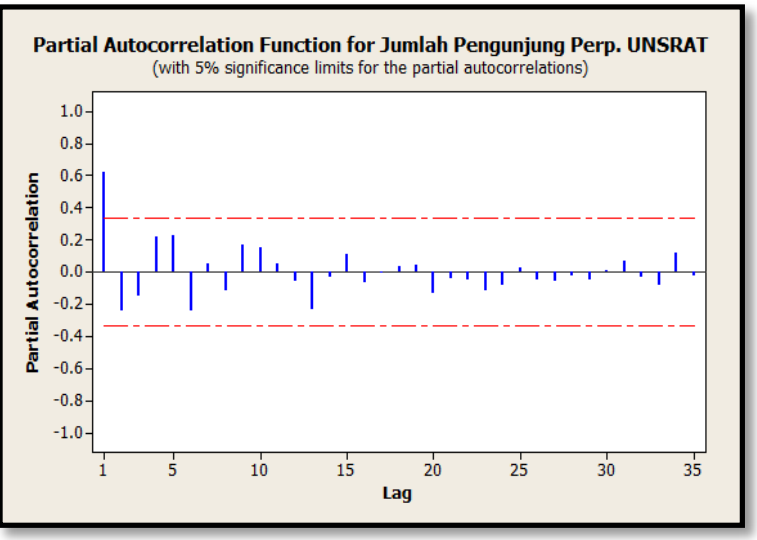

Gambar 3. Grafik Partial Autocorrelation Function (PACF) Ju mlah Pengunjung

Perpustakaan UNSRAT Tahun 2010-2012

Plot yang ditunjukkan grafik ACF dan PACF pada Gambar 2 dan 3 dapat dilihat bahwa data tersebut stasioner karena mendekati 0 setelah lag 1. Dapat dilihat juga bahwa data yang diperoleh bergerak naik dan turun atau berulang pada rentang waktu tertentu sehingga bisa dikatakan bahwa data tersebut memiliki pola data musiman.

\subsection{Menyus un Data per Bulan Masing-masing Tahun}

Banyaknya jumlah pengunjung perpustakaan Universitas Sam ratulangi Manado dalam bulan Januari 2010 - Desember 2012 disajikan pada Tabel 1 berikut ini.

Tabel 1. Data per Bulan Jumlah Pengunjung Perpustakaan UNSRAT

\begin{tabular}{|c|c|c|c|c|c|}
\hline \multirow{2}{*}{ Bulan } & \multicolumn{3}{|c|}{ Juml ah Pengunjung } & \multirow{2}{*}{ Juml ah } & \multirow{2}{*}{ Rata-rata } \\
\cline { 2 - 4 } & $\mathbf{2 0 1 0}$ & $\mathbf{2 0 1 1}$ & $\mathbf{2 0 1 2}$ & & \\
\hline Januari & 962 & 910 & 346 & 2218 & 739,33 \\
\hline Februari & 937 & 919 & 510 & 2366 & 788,67 \\
\hline Maret & 1672 & 1423 & 743 & 3838 & 1279,33 \\
\hline April & 1629 & 1081 & 479 & 3189 & 1063 \\
\hline Mei & 1398 & 1108 & 381 & 2887 & 962,33 \\
\hline Juni & 1043 & 838 & 165 & 2046 & 682 \\
\hline Juli & 467 & 507 & 324 & 1298 & 432,67 \\
\hline Agustus & 295 & 624 & 715 & 1634 & 544,67 \\
\hline September & 623 & 731 & 763 & 2117 & 705,67 \\
\hline Oktober & 1094 & 1359 & 869 & 3322 & 1107,33 \\
\hline
\end{tabular}




\begin{tabular}{|c|c|c|c|c|c|}
\hline November & 1002 & 782 & 721 & 2505 & 835 \\
\hline Desember & 709 & 553 & 338 & 1600 & 533,33 \\
\hline
\end{tabular}

\subsection{Analisis Trend dan Musiman}

Persamaan trend linier untuk data bulanan jumlah pengunjung yaitu $Y_{t}=1157,63-$ 18,1797t. Gambar 4 memperlihatkan analis is komponen untuk data aktual (original data), data tidak trend (detrended data), penyesuaian data musiman (seasonally adjusted data) dan gabungan antara penyesuaian data musiman dan data tidak trend (seasonally adjusted and detrended data).

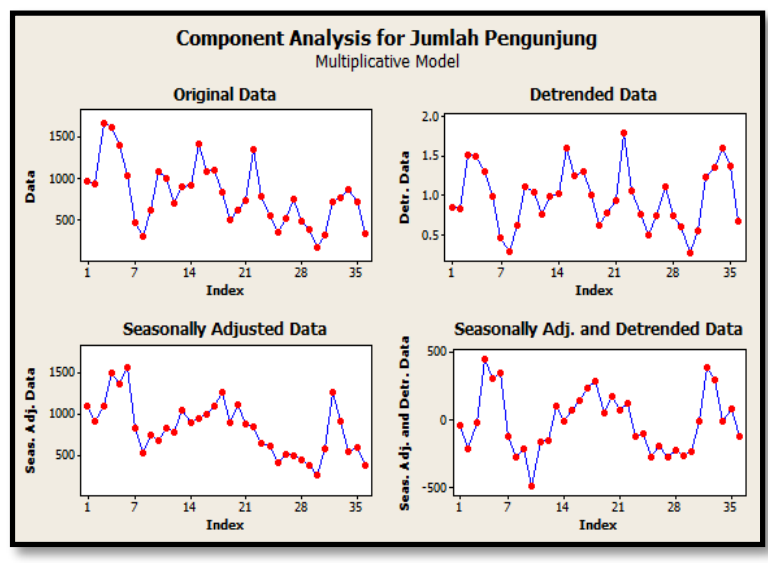

Gambar 4. Analis is Komponen Jumlah Pengunjung Perpustakaan UNSRAT

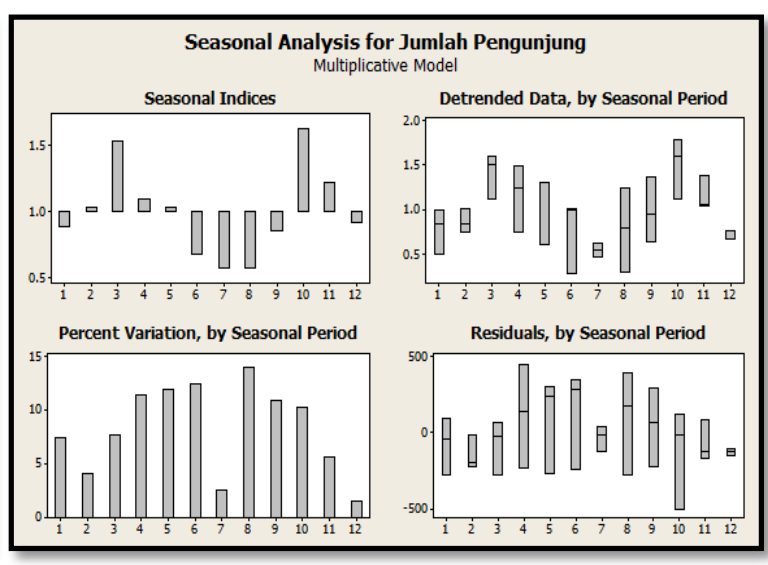

Gambar 5. Analis is Musiman Ju mlah Pengunjung Perpustakaan UNSRAT

Pada Gambar 5 dapat dilihat analis is mus iman, dimana rata-rata nilai indeks mus im yaitu :

Period $1: 0,88405=88 \%$ indeks musim pada bulan pertama.

Period $2: 1,03370=103 \%$ indeks musim pada bulan kedua.

Period $3: 1,53398=153 \%$ indeks musim pada bulan ketiga.

Period $4: 1,09064=109 \%$ indeks musim pada bulan keempat.

Period $5: 1,02734=103 \%$ indeks musim pada bulan kelima.

Period $6: 0,66726=67 \%$ indeks musim pada bulan keenam.

Period $7: 0,57126=57 \%$ indeks musim pada bulan ketujuh.

Period $8: 0,56767=57 \%$ indeks musim pada bulan kedelapan.

Period $9: 0,84974=85 \%$ indeks musim pada bulan kesembilan.

Period $10: 1,63268=163 \%$ indeks musim pada bulan kesepuluh.

Period $11: 1,22458=122 \%$ indeks musim pada bulan kesebelas.

Period $12: 0,91711=92 \%$ indeks musim pada bulan kedua belas .

Analisis musiman menunjukkan bahwa indikasi musiman memiliki nilai harapan sebesar 100\%. Dan hasil yang kita dapat adalah jumlah pengunjung pada bulan pertama adalah $12 \%$ di bawah nilai harapan, bulan kedua adalah 3\% di atas nilai rata-rata, bulan ketiga 53\% di atas nilai rata-rata, bulan keempat $9 \%$ di atas nilai rata-rata, bulan kelima 3\% di atas nilai rata-rata, bulan keenam 33\% di bawah nilai rata-rata, bulan ketujuh $43 \%$ di bawah nilai rata-rata, bulan kedelapan juga $43 \%$ di bawah nilai rata-rata, bulan kesembilan $15 \%$ di bawah nilai rata-rata, bulan kesepuluh $63 \%$ di atas nilai rata-rata, bulan kesebelas $22 \%$ di atas nilai rata-rata dan bulan kedua belas $8 \%$ di bawah rata-rata yang mendekati nilai harapan. Jadi di sini dapat dilihat bahwa bulan kesepuluh memiliki pola musiman yang paling tinggi yaitu $163 \%$, lebih besar $63 \%$ dari indeks musim yang diharapkan. Sedangkan bulan ketujuh dan kedelapan merupakan indeks musim terendah dengan nilai sebesar 57\%, lebih kecil 43\% dari indeks mus im yang diharapkan. 


\subsection{Prediksi Menggunakan Metode Dekomposisi}

1. Trend dan Musiman

Persamaan trend yang diperoleh untuk data bulanan yaitu $Y_{t}=1157,63-18,1797 t$ maka proyeksi trend dan nilai indeks musiman data bulanan untuk tahun 2013 disajikan pada Tabel 2.

Tabel 2. Nilai Trend dan Indeks Musiman Data Bulanan Tahun 2013

\begin{tabular}{|c|c|c|}
\hline \multirow{2}{*}{ Bulan } & Trend & Indeks Musiman \\
\hline I & 484,98 & 0,88405 \\
\hline II & 466,80 & 1,03370 \\
\hline III & 448,62 & 1,53398 \\
\hline IV & 430,44 & 1,09064 \\
\hline V & 412,26 & 1,02734 \\
\hline VI & 394,08 & 0,66726 \\
\hline VII & 375,90 & 0,57126 \\
\hline VIII & 357,72 & 0,56767 \\
\hline IX & 339,54 & 0,84974 \\
\hline X & 321,36 & 1,63268 \\
\hline XI & 303,18 & 1,22458 \\
\hline XII & 285 & 0,91711 \\
\hline
\end{tabular}

\section{Siklis}

Efek siklis didefinisikan sebagai fluktuasi bergelombang di sekitar trend. Pola siklis sulit untuk dimodelkan dalam sebuah time series karena pola ini secara tipikal tidak stabil/ tetap. Fluktuasi seperti gelombang yang naik-turun di sekitar trend jarang terulang di interval waktu yang tetap dan besarnya fluktuasi cenderung bervariasi. Metode dekompos isi dapat diperluas untuk menganalisis data siklis. Akan tetapi, karena sifat yang tidak teratur dari siklis, penganalisaan komponen siklis dari rangkaian sering memerlukan penemuan kejadian yang kebetulan atau kepemimpinan indikator ekonomi.

\section{Irregular}

Komponen irregular menunjukkan adanya keadaan yang bervariasi atau cenderung berubah pada time series setelah komponen lain dihilangkan. Komponen ini disebut residual atau error. Fluktuasi irregular ditunjukkan variasi acak yang tidak dapat diterangkan oleh komponen lain. Dalam hal memprediksi, komponen irregular diatur untuk nilai rata-rata 1,0.

Prediksi jumlah pengunjung perpustakaan UNSRAT Manado untuk bulan pertama sampai dengan bulan kedua belas tahun 2013 adalah dengan mengalikan keempat komponen yaitu trend, musiman, siklis dan irregular masing-masing bulan sehingga menghasilkan nilai prediksi sebagai berikut.

Januari $2013=428,748=428$ pengunjung perpustakaan UNSRAT

Februari $2013=482,535=482$ pengunjung perpustakaan UNSRAT

Maret $2013=688,176=688$ pengunjung perpustakaan UNSRAT

April $2013=469,457=469$ pengunjung perpustakaan UNSRAT

Mei $2013=423,534=423$ pengunjung perpustakaan UNSRAT

Juni $2013 \quad=262,958=262$ pengunjung perpustakaan UNSRAT

Juli $2013=214,739=214$ pengunjung perpustakaan UNSRAT

Agustus $2013=203,068=203$ pengunjung perpustakaan UNSRAT

September $2013=288,525=288$ pengunjung perpustakaan UNSRAT

Oktober $2013=524,686=524$ pengunjung perpustakaan UNSRAT

November $2013=371,274=371$ pengunjung perpustakaan UNSRAT

Desember $2013=261,381=261$ pengunjung perpustakaan UNSRAT 


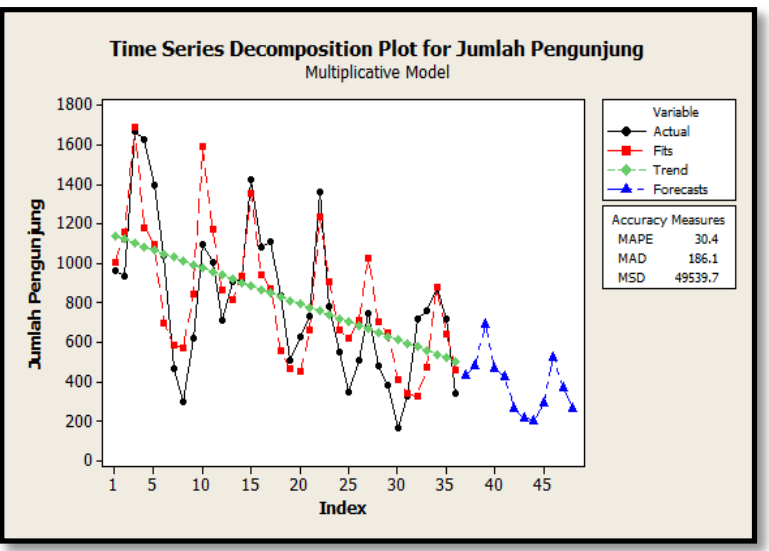

Gambar 6. Plot Data Time SeriesDeko mposisi Model Multip likatif

Gambar 6 memperlihatkan hasil prediksi jumlah pengunjung di perpustakaan UNSRAT Manado tahun 2013. Dalam grafik ditunjukkan juga bahwa terbentuk kecocokan antara komponen trend dan musiman yang berarti data aktual cukup baik. Dapat kita lihat bahwa rata-rata pada bulan Maret dan Oktober pengunjung mengalami kenaikan pesat sedangkan pada bulan Juni sampai Juli dan akhir tahun yaitu bulan November sampai Desember jumlah pengunjung mengalami penurunan. Salah satu penyebab utama pada pola data musiman ini ialah pada bulan Maret dan Oktober merupakan saat dimana kegiatan perkuliahan mahasiswa sangat aktif. Sedangkan pada bulan Juni sampai Agustus dan bulan November sampai Januari merupakan hari perhentian saatsaat kuliah. Namun walaupun pergerakan setiap tahunnya terjadi kenaikan dan penurunan pada saat-saat yang sama, jika dibandingkan dengan data jumlah pengunjung tahun 2012 jumlahnya semakin menurun dibandingkan tahun-tahun sebelumnya.

Hasil prediksi pada tahun 2013 terus menurun dibanding tahun-tahun sebelumnya. Pada kenyataannya bulan Maret dan Oktober memiliki sifat musiman yang cukup tinggi sehingga prediksi pada bulan Maret dan Oktober mempunyai pola data yang kuat dan hasil prediksi pun selalu meningkat pada kedua bulan tersebut.

Berdasarkan uji validasi untuk data pengunjung perpustakaan Universitas Sam Ratulangi bulan Januari - Juni 2013 pada Tabel 3 sesuai dengan plot data time series dari Gambar 7, menunjukkan bahwa selisih antara data aktual dan prediksi semakin besar sejak bulan Januari hingga Juni. Pada kenyataannya bulan Maret memiliki sifat musiman yang cukup tinggi sehingga prediksi pada bulan Maret mempunyai pola data yang kuat dan hasil prediksi pun selalu meningkat pada bulan Maret.

Tabel 3.Uji Validasi Data Pengunjung Perpustakaan Bulan Januari - Juni2013

\begin{tabular}{|c|c|c|c|c|}
\hline \multirow{2}{*}{ Bulan } & \multicolumn{2}{|c|}{ Juml ah Pengunjung } & \multirow{2}{*}{$\begin{array}{c}\text { Galat/Error } \\
\left(e_{i}\right)\end{array}$} & \multirow{2}{*}{$e_{i}^{2}$} \\
\hline & Aktual $\left(X_{i}\right)$ & Ramalan $\left(F_{i}\right)$ & & \\
\hline Januari & 754 & 732.4 & 21.6 & 466.56 \\
\hline Februari & 948 & 853.97 & 94.03 & 8841.64 \\
\hline Maret & 974 & 1263.69 & -289.69 & 83920.3 \\
\hline April & 1412 & 895.93 & 516.07 & 266328.25 \\
\hline Mei & 1480 & 841.53 & 638.47 & 407643.94 \\
\hline Juni & 1766 & 545.03 & 1220.97 & 1490767.74 \\
\hline Jumlah & 7334 & 5132.55 & 2201.45 & 2257968.42 \\
\hline
\end{tabular}

$$
M S E(\text { data bulanan })=\frac{1}{n} \sum_{t=1}^{n}\left(X_{i}-F_{i}\right)^{2}=\frac{4846382}{6}=807730.33
$$




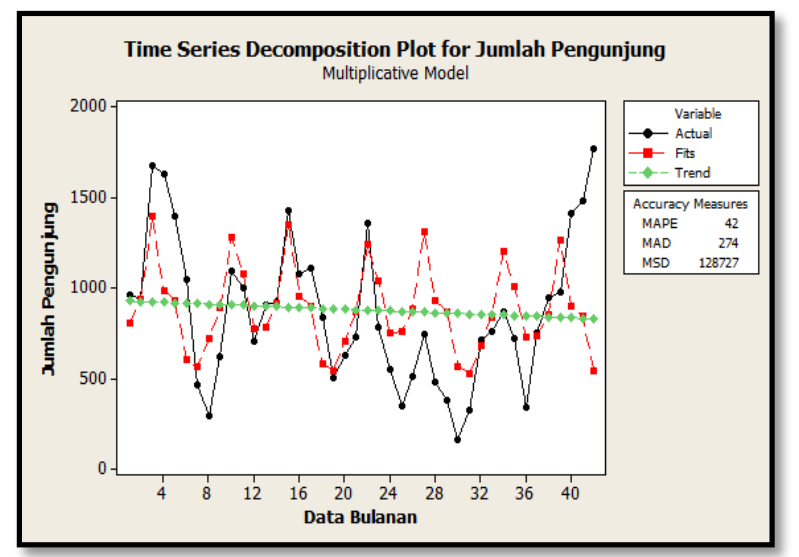

Gambar 7. Plot Data Time Series Dekomposisi Jumlah Pengunjung Perpustakaan UNSRAT

\section{Kesimpulan}

Berdasarkan hasil analisis data dan pembahasan yang telah dilakukan maka dapat ditarik kesimpulan sebagai berikut :

1. Model persamaan trend linier yang didapat dari hasil jumlah pengunjung di Perpustakaan Universitas Sam Ratulangi Manado dengan menggunakan data bulanan yaitu $Y_{t}=1157,63-$ 18,1797 t. Indikasi musiman nilai harapannya sebesar $100 \%$. Hasil yang diperoleh untuk periode Januari - Desember 2013, nilai harapannya sebagai berikut : $88 \%, 103 \%, 153 \%, 109 \%, 103 \%, 67 \%, 57 \%, 57 \%, 85 \%, 163 \%, 122 \%$ dan $92 \%$.

2. Jumlah pengunjung di Perpustakaan Universitas Sam Ratulangi Manado dengan menggunakan metode dekomposisi model multiplikatif dari Januari - Desember 2013 berturut-turut sebagai berikut :

428 pengunjung, 482 pengunjung, 688 pengunjung, 469 pengunjung, 423 pengunjung, 262 pengunjung, 214 pengunjung, 203 pengunjung, 288 pengunjung, 524 pengunjung, 371 pengunjung dan 261 pengunjung. Prediksi jumlah pengunjung di Perpustakaan Universitas Sam Ratulangi Manado terjadi kenaikan pada Bulan Maret dan Oktober sedangkan pada Bulan Juni sampai Juli dan Bulan November sampai Desember jumlah pengunjung mengalami penurunan.

\section{Daftar Pus taka}

[1] Assauri, S. 1984. Teknik dan Metode Peramalan. Fakultas Ekonomi UI, Jakarta.

[2] Makridakis, S. S. C., dan Wheelwright. Dan V. E. McGeee. 1993. Metode dan Aplikasi Peramalan. Jilid 1. Edisi Pertama. Terje mahan Hari Su minto. Binarupa Aksara, Jakarta.

[3] Martika, D. M. 2007. Peramalan Jumlah Pengunjung Dengan Metode Dekomposisi serta Kontribusi Jumlah Pengunjung Terhadap Pendapatan Objek Wisata Pantai Purwahamba Indah Tegal.Tugas Akhir Diplo ma 3 Statistik Terapan dan Komputasi.Universtias Negeri Semarang.

[4] Putra, A. T., dkk. 2013. Forecasting of Sheath Demand Using Time Series Model Autoregressive Integrated Moving Average and Minimization of Forecasting Results of The Total Cost Using WagnerWithin. Jurnal Science East Borneo.1:31-39.

[5] Subagyo, P. 1986. Forecasting Konsep dan Aplikasi. BPFE, Yogyakarta.

[6] Sutarno, N. S. 2006. Perpustakaan dan Masyarakat. Jakarta: Sagung Seto.

[7] Taufik, A. A. 2005. Peramalan Banyaknya Pengunjung Perpustakaan Tahun 2006 dengan Metode Dekomposisi pada Kantor Perpustakaan Kabupaten Pemalang.Tugas Akhir Diploma 3 Statistik Terapan dan Komputasi.Universitas Negeri Semarang. 